J. Dairy Sci. 97:2297-2304

http://dx.doi.org/10.3168/jds.2013-7066

(C) American Dairy Science Association ${ }^{\circledR}, 2014$.

\title{
Effects of lipid and propionic acid infusions on feed intake of lactating dairy cows
}

\author{
S. E. Stocks and M. S. Allen ${ }^{1}$ \\ Department of Animal Science, Michigan State University, East Lansing 48824-1225
}

\begin{abstract}
Propionic acid is more hypophagic for cows with elevated hepatic acetyl coenzyme A (CoA) concentration in the postpartum period. The objective of this experiment was to evaluate the interaction of hepatic acetyl CoA concentration, which is elevated by intravenous lipid infusion, and intraruminal propionic acid infusion on feed intake and feeding behavior responses of lactating cows. Eight multiparous, ruminally cannulated, Holstein dairy cows past peak lactation were used in a replicated $4 \times 4$ Latin square experiment with a 2 $\times 2$ factorial arrangement of treatments. Treatments were propionic acid (PI) infused intraruminally at 0.5 $\mathrm{mol} / \mathrm{h}$ for $18 \mathrm{~h}$ starting $6 \mathrm{~h}$ before feeding and behavior monitoring or sham control (CO), and intravenous jugular infusion of lipid (LI, Intralipid 20\%; Baxter US, Deerfield, IL) or saline (SI, $0.9 \% \mathrm{NaCl}$; Baxter US) infused at $250 \mathrm{~mL} / \mathrm{h}$ for $12 \mathrm{~h}$ before feeding and behavior monitoring, and then $500 \mathrm{~mL} / \mathrm{h}$ for $12 \mathrm{~h}$ after feeding. Changes in plasma concentrations of metabolites and hormones and hepatic acetyl CoA from before infusion until the end of infusion were evaluated. We observed a tendency for an interaction between PI and LI for the change in plasma nonesterified fatty acid (NEFA) concentration from the preliminary day to the end of the infusion period. Infusion of propionic acid decreased dry matter intake (DMI) 15\% compared with $\mathrm{CO}$, but lipid infusion did not affect DMI over the $12 \mathrm{~h}$ following feeding. Infusion of propionic acid tended to decrease hepatic acetyl CoA concentration from the preliminary day to the end of the infusion compared with CO, consistent with PI decreasing DMI by stimulating oxidation of acetyl CoA. Contrary to our expectations, LI did not increase concentration of NEFA or $\beta$-hydroxybutyrate in plasma, concentration of acetyl $\mathrm{CoA}$ in the liver, or milk fat yield, suggesting that the infused lipid was stored or oxidized by extrahepatic tissues. As a result, we detected no interaction between PI and LI for DMI. Although the effect of PI
\end{abstract}

Received May 25, 2013.

Accepted December 5, 2013.

${ }^{1}$ Corresponding author: allenm@msu.edu on DMI was consistent with our previous results, this lipid infusion model using cows past peak lactation was not useful to simulate the lipolytic state of cows in the postpartum period in this experiment.

Key words: hepatic oxidation, hypophagia, lipid metabolism, propionate metabolism

\section{INTRODUCTION}

Dairy cows undergo substantial metabolic adaptations as they transition from late gestation to lactation. Energy demands are $\sim 3$-fold greater for lactation than for late gestation (as reviewed by Bell, 1995), and feed intake is often suppressed postpartum, resulting in negative energy balance (Doepel et al., 2002). Plasma glucose and insulin concentrations are low and tissue sensitivity to insulin is reduced during the immediate postpartum period (Bell and Bauman, 1997), elevating plasma NEFA and BHBA concentrations (Doepel et al., 2002). Elevated serum BHBA concentration greatly increases the risk of displaced abomasum, whereas elevated serum NEFA concentration increases risk of ketosis and likelihood of culling in the first $60 \mathrm{~d}$ postpartum (Seifi et al., 2011; Roberts et al., 2012). Therefore, careful management of the nutritional program through this time is necessary to meet the nutrient demands of cows in the first weeks following parturition to limit the extent and duration of lipolysis.

During the postpartum period, starch concentration in the diet is increased to provide glucose precursors to support milk production. As reviewed by Firkins et al. (2001), ruminal starch fermentability ranges from approximately 45 to $87 \%$, depending on the type and processing of corn, and higher ruminal starch fermentability increases propionate production in the rumen as a fraction of total VFA (Davis, 1967). Propionate accounts for about $60 \%$ of the total hepatic glucose production for cows in early lactation (Reynolds, et al., 2003). However, previous research in our laboratory has demonstrated that propionic acid is hypophagic during the immediate postpartum period (Oba and Allen, 2003a; Stocks and Allen, 2012, 2013) and the extent of hypophagia is greater when cows are in a lipolytic state (Stocks and Allen, 2012, 2013). Our laboratory 
has also shown that increasing glucose demand with phlorizin reduces DMI, presumably by stimulating lipolysis (Bradford and Allen, 2007). These results are consistent with greater hypophagic effects of propionate for cows in a lipolytic state.

Despite this evidence that propionic acid is more hypophagic when cows are in a lipolytic state, experiments to test cause and effect between lipolytic state and propionic acid infusion on DMI are necessary. Experimental elevation of plasma NEFA concentration combined with infusion of propionic acid to test interactions among treatments for effects on feeding behavior will allow the interactions detected to be specifically attributed to increased oxidation of acetyl CoA. Lipid infusion is expected to increase NEFA supply to the liver and increase flux of carbon through acetyl CoA. The objective of this experiment was to evaluate the interaction of hepatic acetyl CoA concentration (which is elevated by intravenous lipid infusion) and intraruminal propionic acid infusion on feed intake and feeding behavior responses of lactating cows. We hypothesized that the hypophagic effects of propionic acid will be enhanced for cows receiving the lipid infusion.

\section{MATERIALS AND METHODS}

\section{Animals, Housing, and Diets}

The Institutional Animal Care and Use Committee at Michigan State University approved all experimental procedures for this experiment. Eight lactating, ruminally cannulated Holstein cows past peak lactation (81-252 DIM), with mean BW of $718 \mathrm{~kg}( \pm 11 \mathrm{~kg})$ and mean BCS of $2.65( \pm 0.54)$, were housed in individual tiestalls for the duration of the experiment. One cow was removed from the experiment because feed intake and milk yield were reduced by more than $75 \%$ after initiation of lipid infusion. Cows were fed at $115 \%$ of expected intake and received a common experimental diet. The experimental diet (Table 1) included corn silage, alfalfa silage, soybean meal, ground corn, and a mineral and vitamin mix, and it was formulated to meet requirements for absorbed protein, minerals, and vitamins (NRC, 2001).

\section{Experimental Design and Treatments}

The experimental design was a duplicated $4 \times 4$ Latin square with a $2 \times 2$ factorial arrangement of treatments. Cows were randomly assigned to block and treatment sequence, and squares were balanced for carryover effects. The experiment lasted $24 \mathrm{~d}$ and included an 8-d diet adaptation period followed by 4 infusion periods, each with $2 \mathrm{~d}$ for determination of digestibility, a 1-d preliminary period, and a 1-d infusion period (Table 2). On d 8, cows were fitted with bilateral jugular catheters according to Bradford et al. (2006) and catheters were maintained for the duration of the experiment. The treatments were propionic acid $(1 \mathrm{~mol} / \mathrm{L} ; \mathbf{P I})$ infused continuously into the rumen at $500 \mathrm{~mL} / \mathrm{h}$ for $18 \mathrm{~h}$ beginning $6 \mathrm{~h}$ before feeding or sham control (CO) and intravenous drip infusion of $20 \%$ Intralipid (LI; Baxter US, Deerfield, IL) or physiological saline (SI; 0.9\% sodium chloride, $\mathrm{pH}$ 5.5; Baxter US) infused at $250 \mathrm{~mL} / \mathrm{h}$ for $12 \mathrm{~h}$ before feeding and then $500 \mathrm{~mL} / \mathrm{h}$ for the next $12 \mathrm{~h}$. The lipid and saline control infusions were initiated at a lower rate to allow for a gradual increase in blood lipid concentration to avoid complications from inadequate adaptation. Propionic acid infusion began $6 \mathrm{~h}$ before feeding to allow propionate concentration in the rumen to approach steady state before measurement of feeding behavior. Propionic acid was infused using peristaltic pumps (no. 78016-30, Cole-Parmer Instrument, Vernon Hills, IL) with Tygon tubing (1.6 $\mathrm{mm}$ i.d.). The infusates were pumped from individual 1-L bottles that were manually refilled hourly to ensure accurate infusion rates.

\section{Data and Sample Collection}

Cows were blocked from feed from 1000 to $1200 \mathrm{~h}$ each day of the experiment to collect and weigh orts and to offer feed. Samples of all diet ingredients $(0.5$ $\mathrm{kg})$ and orts (12.5\% of remaining feed) were collected for the $3 \mathrm{~d}$ before each infusion day and on the infusion day and composited by infusion period. Body weight and BCS were recorded on d 1 of the experiment. Body condition was scored by 3 trained investigators on a 5 -point scale, where $1=$ thin and $5=$ fat, as described

Table 1. Ingredients and nutrient composition of experimental diet (\% of dietary DM except for DM)

\begin{tabular}{lc}
\hline Item & $\%$ \\
\hline Ingredient & \\
Corn silage & 50.7 \\
Alfalfa silage & 28.9 \\
Ground corn & 9.7 \\
Soybean meal & 6.2 \\
Vitamin and mineral mix ${ }^{1}$ & 4.6 \\
Nutrient composition & \\
DM & 51.6 \\
OM & 92.4 \\
Starch & 21.1 \\
NDF & 36.3 \\
ADF & 23.9 \\
CP & 13.7 \\
\hline
\end{tabular}

${ }^{1}$ Vitamin and mineral mix contained $60.4 \%$ ground corn grain, $18.8 \%$ limestone, $8.8 \%$ sodium bicarbonate, $4.0 \%$ urea, $3.1 \%$ magnesium sulfate, $2.9 \%$ salt, $0.63 \%$ trace mineral mix, $0.63 \%$ biotin, $0.63 \%$ vitamin ADE premix, and $0.20 \%$ selenium yeast. 
Table 2. Time course of events within each period

\begin{tabular}{lll}
\hline Day of period & Time of day & Event \\
\hline 1 & 1200 and $2100 \mathrm{~h}$ & Feces collected for digestibility determination \\
2 & 0600,1500, and $2400 \mathrm{~h}$ & Feces collected for digestibility determination \\
3 (Preliminary) & $1000 \mathrm{~h}$ & Liver, blood, and rumen fluid samples collected \\
4 (Infusion) & $0000 \mathrm{~h}$ & Intravenous lipid or saline infusion initiated at $50 \%$ rate \\
4 & $0600 \mathrm{~h}$ & $\begin{array}{l}\text { Propionic acid infusion initiated } \\
4\end{array}$ \\
4 & $12000-1200 \mathrm{~h}$ & Access to feed denied to collect orts and supply feed \\
4 & $2400 \mathrm{~h}$ & Intravenous lipid or saline infusion rate increased to $100 \%$, feeding behavior monitoring \\
& initiated, access to feed granted
\end{tabular}

by Wildman et al. (1982). Cows were milked twice daily at 0500 and $1700 \mathrm{~h}$ in their stalls on infusion days and in the milking parlor on all other days. Milk samples were collected from each milking on the day before the infusion and on the infusion day, and each sample was analyzed for fat, true protein, lactose, and SNF by Michigan DHIA (AOAC International, 1997).

Fecal samples were collected every $9 \mathrm{~h}$ over the $3 \mathrm{~d}$ before each infusion $(\mathrm{n}=5)$ and frozen at $-20^{\circ} \mathrm{C}$ for later analysis to determine diet digestibility for use in calculating ME intake. Fecal samples were composited to one sample per cow per period before analysis. $\mathrm{Ru}-$ men fluid, liver, and blood samples were collected $1 \mathrm{~d}$ before each infusion day in each period (preliminary day) before feeding at $1000 \mathrm{~h}$ and on the infusion day 12 $\mathrm{h}$ after feeding at $2400 \mathrm{~h}$ and each sample was analyzed individually. Rumen fluid samples were collected from 5 different sites in the rumen and squeezed through a nylon screen; $\mathrm{pH}$ was determined immediately. Samples were stored at $-20^{\circ} \mathrm{C}$ for later analysis for VFA concentrations. Liver tissue was collected by needle biopsy (Bradford and Allen, 2005) and stored at $-80^{\circ} \mathrm{C}$ until analysis for acetyl CoA concentration. Blood samples were collected by coccygeal venipuncture into $2 \mathrm{Vacu}-$ tainer tubes (Becton Dickinson, Franklin Lakes, NJ): 1 tube contained potassium EDTA and 1 tube contained potassium oxalate and sodium fluoride (as a glycolytic inhibitor). Blood samples were cooled on ice until centrifuged at 2,000 $\times \mathrm{g}$ for $20 \mathrm{~min}$ (within $15 \mathrm{~min}$ of sample collection); plasma was harvested and frozen at $-20^{\circ} \mathrm{C}$ for later analysis of metabolites and hormones. A 1-mL aliquot of plasma from each potassium EDTA tube was stored with $0.05 \mathrm{M}$ benzamidine (final concentration) to prevent enzymatic degradation of glucagon.

Feeding behavior was monitored for $12 \mathrm{~h}$ (1200 to $2400 \mathrm{~h}$ ) on infusion days. Feeding behavior data (feed disappearance and water intake) were recorded via computer every $5 \mathrm{~s}$, and size, length, and frequency of meals, intermeal interval, total eating time, and water intake were calculated (Dado and Allen, 1993).

\section{Analysis of Samples}

Feed, orts, and fecal samples were dried in a $55^{\circ} \mathrm{C}$ forced-air oven for $72 \mathrm{~h}$ and analyzed for DM concentration. All samples were ground with a Wiley mill (1mm screen; Arthur H. Thomas, Philadelphia, PA) and analyzed for ash, NDF, indigestible NDF, CP, starch, and ether extract. Ash concentration was determined after $5 \mathrm{~h}$ of oxidation at $500^{\circ} \mathrm{C}$. Concentration of NDF was analyzed according to Mertens (2002). Indigestible NDF was used as an internal marker to estimate total-tract nutrient digestibility (Cochran et al., 1986), and indigestible NDF was estimated as NDF residue after $240 \mathrm{~h}$ of in vitro fermentation (Goering and Van Soest, 1970). Rumen fluid for the in vitro incubation was collected from a nonpregnant dry cow fed dry hay only and flasks were re-inoculated at $120 \mathrm{~h}$ to ensure a viable microbial population. Crude protein was determined according to Hach et al. (1987). Starch was analyzed using an enzymatic method (Karkalas, 1985) after samples were gelatinized with sodium hydroxide. Glucose was measured using a glucose oxidase method (PGO Enzyme product No. P7119, Sigma Chemical Co., St. Louis, MO). Ether extract was determined using a modified Soxhlet apparatus (AOAC, 1990). All nutrients are expressed as percentages of DM determined by drying at $105^{\circ} \mathrm{C}$ in a forced air oven for more than $8 \mathrm{~h}$.

Plasma samples were analyzed using commercial kits for concentration of NEFA (NEFA HR kit, Wako Chemicals USA, Richmond, VA), BHBA (kit no. 2240, Stanbio Laboratory, Boerne, TX), insulin (Coat-ACount, Siemens Healthcare Diagnostics, Deerfield, IL), and glucagon (kit no. GL-32K, Millipore, Billerica, MA). Plasma glucose concentration was analyzed using the glucose oxidase method described above. Plasma and rumen fluid VFA concentrations were determined by HPLC according to Oba and Allen (2003b). Liver acetyl CoA was analyzed by HPLC using a method described previously (Stocks and Allen, 2012). 


\section{Statistical Analysis}

Feeding behavior, intake, metabolite and hormone responses, and rumen fermentation characteristics were analyzed using the Fit Model procedure of JMP (version 10.0.0, 2012; SAS Institute Inc., Cary, NC) with the following model:

$$
\mathrm{Y}_{\mathrm{ijkl}}=\mu+\mathrm{S}_{\mathrm{i}}+\mathrm{C}\left(\mathrm{S}_{\mathrm{i}}\right)_{\mathrm{j}}+\mathrm{P}_{\mathrm{k}}+\mathrm{T}_{1}+\mathrm{P}_{\mathrm{k}} \mathrm{T}_{1}+\mathrm{e}_{\mathrm{ijk} \mathrm{k}},
$$

where $\mathrm{Y}_{\mathrm{ijkl}}=$ the dependent response variable of interest, $\mu=$ overall mean, $\mathrm{S}_{\mathrm{i}}=$ fixed effect of square $(\mathrm{i}=$ 1 to 2$), C\left(S_{i}\right)_{j}=$ random effect of cow within square $(\mathrm{j}=4), \mathrm{P}_{\mathrm{k}}=$ fixed effect of period $(\mathrm{k}=1$ to 4$), \mathrm{T}_{1}=$ fixed effect of treatment $(\mathrm{l}=1$ to 4$), \mathrm{P}_{\mathrm{k}} \mathrm{T}_{1}=$ period $\times$ treatment interaction, and $e_{i j k l}=$ residual, normally distributed. Treatment effects were declared significant at $P \leq 0.05$ and tendencies for treatment effects at $P$ $\leq 0.10$. Interactions were declared significant at $P \leq$ 0.10 and tendencies for interactions at $P \leq 0.15$. All data are expressed as least squares means and standard error of the means, unless otherwise specified.

\section{RESULTS}

\section{Plasma Metabolite and Hormone and Liver Metabolite Concentrations}

Concentrations of plasma metabolites and hormones and hepatic acetyl CoA are reported in Table 3 for cows at $1000 \mathrm{~h}$ on the day before infusion (preliminary day) and at $2400 \mathrm{~h}$ following infusion (infusion day) as well as the difference between these 2 times (after infusion minus preliminary). The LI treatment increased plasma insulin concentration $(P=0.04)$ and insulin:glucagon ratio $(P=0.02)$ to a lesser extent than the SI treatment, but decreased plasma glucose $(P=0.04)$ concentration more than SI. Propionic acid infusion suppressed the increase in plasma glucagon concentration compared with CO $(P=0.02)$. The PI treatment tended to decrease hepatic acetyl CoA concentration from the preliminary day to the end of the infusion compared with $\mathrm{CO}(-5.7$ vs. $-2.4 \mathrm{nmol} / \mathrm{g}$ of wet tissue; $P=0.09)$. We detected a tendency for an interaction between PI and LI for the change in plasma NEFA concentration from the preliminary day to the end of the infusion period $(P=0.12)$; PI decreased plasma NEFA more during SI and less during LI. No other interactions were detected between PI and LI for any change in plasma or liver metabolites or plasma hormones $(P>0.17)$.

\section{Milk Production and Feed Intake}

Milk production and component yields on the infusion days are reported in Table 4 . We observed a tendency for an interaction between PI and LI for milk protein and lactose yields $(P=0.14$ and $P=0.11$, respectively), which are a result of reduced yields of both for the SI-PI treatment. No additional main effects or interactions of treatments were detected between PI and LI for yields of milk or milk components $(P>$ $0.29)$.

Feed intake and feeding behavior are reported in Table 5. Intraruminal PI decreased daily DMI $(P=$ $0.01)$ and DMI over the 12 -h infusion period $(P=0.02)$ and tended to decrease intake over the first $4 \mathrm{~h}$ following feeding $(P=0.07)$, but did not affect DMI during the $12 \mathrm{~h}$ following the termination of the infusion $(P=$ 0.40) compared with CO. The PI treatment decreased water intake $(P=0.01)$ compared with $\mathrm{CO}$, but did not affect dietary ME energy intake or total ME intake compared with CO $(P>0.10)$. The LI treatment did not affect dietary ME intake but tended to increase total ME intake $(P=0.06)$ compared with SI. Intrajugular LI increased meal frequency $(P=0.03)$, reduced meal length $(P=0.05)$, and tended to reduce meal size $(P=$ $0.06)$ and intermeal interval $(P=0.08)$ compared with SI. We observed a tendency for an interaction between LI and PI for meal frequency and intermeal interval $(P$ $=0.12$ for both); LI increased meal frequency and decreased the interval between meals more with PI than with CO. We observed no other interactions between LI and PI for any other feed intake or feeding behavior response measured $(P>0.30)$.

\section{Ruminal $\mathrm{pH}$ and Concentration and Profile of VFA}

Rumen $\mathrm{pH}$ and concentration and profile of VFA are reported in Table 6 . Ruminal $\mathrm{pH}$ was not affected by treatment infusions. Intraruminal PI increased both the concentration and percentage of propionic acid $(P<$ 0.001 for both) and decreased the concentration and percentage of both acetic and butyric acid $(P=0.02)$ in the rumen. Intrajugular LI tended to increase the total VFA $(P=0.06)$, and increased concentrations of acetic, butyric, and isovaleric acids $(P<0.05)$ in the rumen. We detected no interactions between rumen PI and LI on rumen VFA concentration $(P>0.35)$, but tendencies were detected for interactions of PI and LI for the percentage of acetic, butyric, and isobutyric acids $(P=$ $0.11,0.10$, and 0.14 , respectively) in the rumen.

\section{DISCUSSION}

The lipid infusion in this experiment was expected to simulate the lipolytic state of cows in the postpartum period by increasing NEFA supply to, and oxidation in, the liver, as previously observed (Mashek et al., 2005; Pires et al., 2007). In the present study, intrajugular 
Table 3. Concentrations and change in concentration of plasma metabolites and hormones and hepatic acetyl CoA for cows at $1000 \mathrm{~h}$ on the day before infusion (preliminary day) and at $2400 \mathrm{~h}$ following infusion (infusion day)

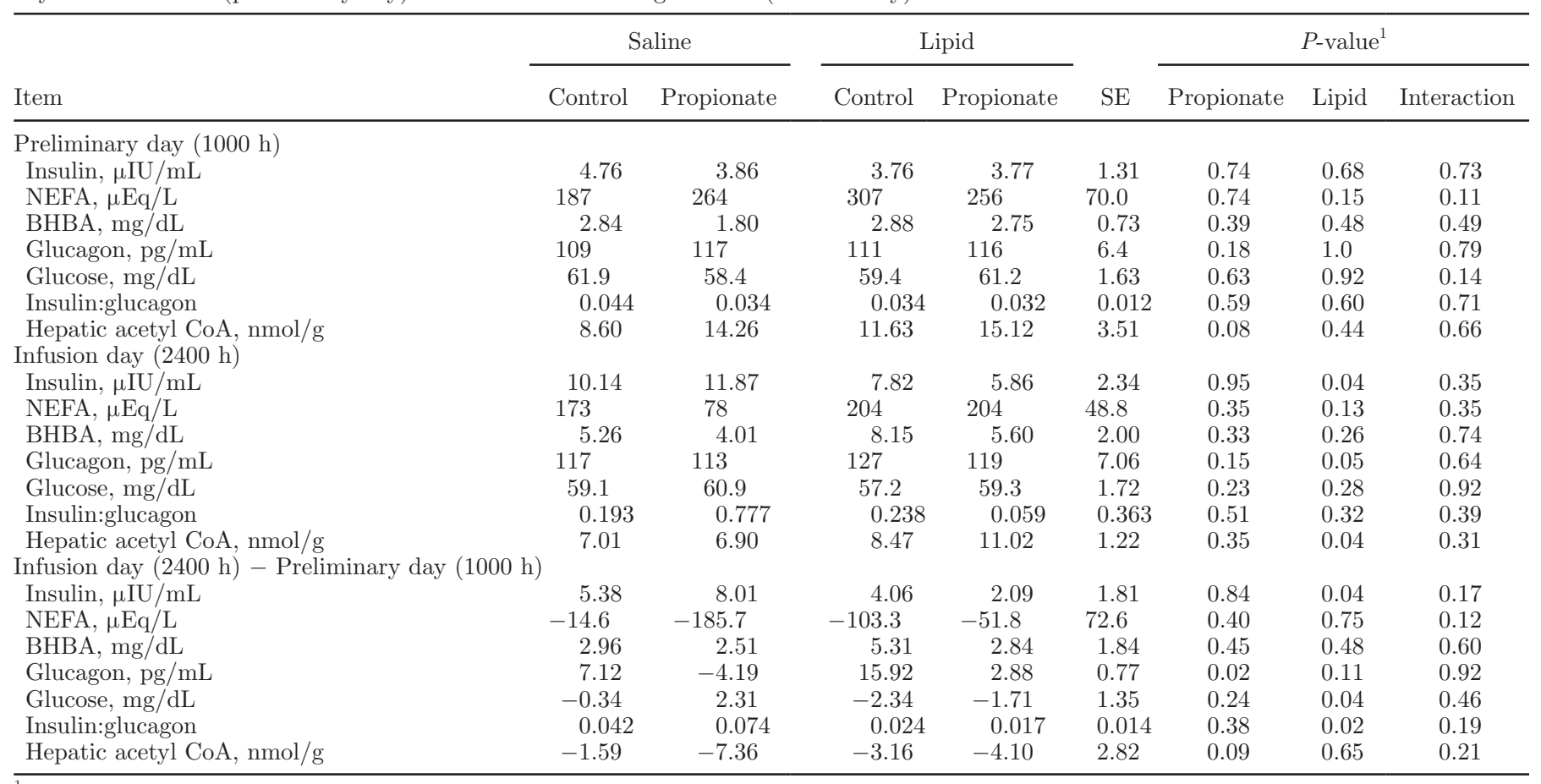

${ }^{1}$ Interaction $=$ interaction between propionic acid and lipid infusion.

infusion of Intralipid (Baxter US) failed to achieve the desired results. Previous reports using lipid infusions at similar rates to those in the current experiment have resulted in metabolic profiles that are consistent with our expected response of increased plasma NEFA concentration. Pires et al. (2007) infused a $20 \%$ tallow emulsion at a rate of $\sim 72 \mathrm{~g}$ of triglycerides $(\mathbf{T G}) / \mathrm{h}$ in nonlactating, nongestating Holstein cows and reported a 3.7 -fold increase in plasma NEFA concentration within $2 \mathrm{~h}(P$ $<0.001$ ), reaching a peak by $8 \mathrm{~h}$ of infusion. They also reported an increase in plasma glucose and serum insulin concentrations within $8 \mathrm{~h}$ of infusion. Mashek et al. (2005) infused $16 \mathrm{~g}$ of TG/h of $20 \%$ lipid emulsions (based on tallow, linseed, or fish oil) into nonlactating, nongestating, fasted Holstein cows and reported that, regardless of lipid source, plasma NEFA was increased, with tallow increasing plasma NEFA to the greatest extent. Chelikani et al. (2003) infused lipid at a rate of $\sim 69 \mathrm{~g}$ of $\mathrm{TG} / \mathrm{h}$ for $6 \mathrm{~h}$ into cows in late lactation and reported an 8-fold increase in plasma NEFA concentration within the first $3 \mathrm{~h}$ of infusion, with no difference in plasma glucose or insulin concentrations. Bareille and Faverdin (1996) infused $131 \mathrm{~g}$ of TG/h for $4 \mathrm{~h}$ into cows $\sim 60$ and 92 DIM and reported increases in plasma NEFA, glucose, and insulin concentrations. The variation in plasma hormone and metabolite responses

Table 4. Effects of treatment on yield of milk and milk components for cows on the day of infusion

\begin{tabular}{|c|c|c|c|c|c|c|c|c|}
\hline \multirow[b]{2}{*}{ Item } & \multicolumn{2}{|c|}{ Saline } & \multicolumn{2}{|c|}{ Lipid } & \multirow[b]{2}{*}{ SE } & \multicolumn{3}{|c|}{$P$-value ${ }^{1}$} \\
\hline & Control & Propionate & Control & Propionate & & Propionate & Lipid & Interaction \\
\hline Milk & 32.8 & 28.7 & 31.0 & 31.3 & 4.28 & 0.36 & 0.84 & 0.29 \\
\hline Milk fat & 1.37 & 1.23 & 1.31 & 1.21 & 0.17 & 0.19 & 0.67 & 0.85 \\
\hline Milk protein & 1.03 & 0.83 & 1.01 & 1.01 & 0.11 & 0.16 & 0.26 & 0.14 \\
\hline Milk lactose & 1.56 & 1.22 & 1.50 & 1.51 & 0.20 & 0.12 & 0.27 & 0.11 \\
\hline Milk fat & 4.23 & 4.66 & 4.23 & 3.89 & 0.40 & 0.89 & 0.30 & 0.30 \\
\hline Milk protein & 3.18 & 3.25 & 3.32 & 3.32 & 0.23 & 0.83 & 0.53 & 0.82 \\
\hline Milk lactose & 4.73 & 4.30 & 4.78 & 4.74 & 0.19 & 0.24 & 0.22 & 0.31 \\
\hline
\end{tabular}

\footnotetext{
${ }^{1}$ Interaction $=$ interaction between propionic acid and lipid infusion.
} 
Table 5. Effects of treatment on feeding behavior for cows on the day of infusion

\begin{tabular}{|c|c|c|c|c|c|c|c|c|}
\hline Item & \multicolumn{2}{|c|}{ Saline } & \multicolumn{2}{|c|}{ Lipid } & $\mathrm{SE}$ & \multicolumn{3}{|c|}{$P$-value ${ }^{1}$} \\
\hline \multicolumn{9}{|l|}{ Feeding behavior } \\
\hline DMI, kg/12 h (1200-2400 h) & 20.0 & 16.3 & 17.9 & 15.9 & 1.45 & 0.02 & 0.30 & 0.44 \\
\hline DMI, kg/4 h (1200-1600 h) & 12.2 & 10.2 & 10.9 & 10.1 & 1.48 & 0.07 & 0.35 & 0.41 \\
\hline DMI, kg/12 h (2400-1200 h) & 8.3 & 7.8 & 8.1 & 7.4 & 0.75 & 0.40 & 0.68 & 0.93 \\
\hline Meal size, $\mathrm{kg} / \mathrm{meal}$ & 3.98 & 4.23 & 3.35 & 2.74 & 0.66 & 0.72 & 0.06 & 0.42 \\
\hline Intermeal interval, min & 104.7 & 147.8 & 100.4 & 93.8 & 17.0 & 0.25 & 0.08 & 0.12 \\
\hline Ruminating bouts, no. $/ 12 \mathrm{~h}$ & 5.77 & 5.08 & 5.96 & 6.37 & 0.82 & 0.84 & 0.28 & 0.43 \\
\hline Chew time, $\min / 12 \mathrm{~h}$ & 364.9 & 342.8 & 402.2 & 360.5 & 24.6 & 0.13 & 0.17 & 0.63 \\
\hline \multicolumn{9}{|l|}{ ME intake, ${ }^{2} \mathrm{MJ} / 12 \mathrm{~h}$} \\
\hline Diet & 178 & 155 & 174 & 152 & 14.8 & 0.12 & 0.76 & 0.99 \\
\hline
\end{tabular}

${ }^{1}$ Interaction $=$ interaction between propionic acid and lipid infusion.

${ }^{2} \mathrm{ME}$ intake from the diet was calculated according to Oba and Allen (2003a).

${ }^{3} \mathrm{ME}$ intake from the propionic acid infusion was based on energy density of $1.536 \mathrm{MJ} / \mathrm{mol}$ for propionic acid (Oba and Allen, 2003a), respectively, and was the same for all cows; ME from lipid was $4.2 \mathrm{MJ} / \mathrm{h}$ of lipid infusion during the feeding behavior period.

could be the result of differences in amount of TG infused or stage of lactation between the studies.

Despite an infusion rate that was within the range of TG infused in previous reports (92.6 $\mathrm{g}$ of TG/h), LI did not increase plasma NEFA concentration. This could be a result of increased storage or oxidation of lipid, or transfer of lipid to milk fat. In the current experiment, LI was infused at half the final rate for the first $12 \mathrm{~h}$ of infusion ( $46.3 \mathrm{~g}$ of $\mathrm{TG} / \mathrm{h}$ ) to allow for adaptation to avoid adverse reactions, such as increased body temperature or respiration rate. During this time, LI increased plasma NEFA concentration from $282 \mu \mathrm{Eq} / \mathrm{L}$ on the preliminary day to $385 \mu \mathrm{Eq} / \mathrm{L}$ at the start of feeding behavior (data not shown). In the experiments previously mentioned, plasma NEFA concentration was elevated within the first 3 to $8 \mathrm{~h}$ of initiating the lipid infusion. It is possible that metabolic adaptations to LI occurred during the initial 12-h TG infusion that resulted in less dramatic responses to LI during the 12-h feeding behavior monitoring period. We considered infusing heparin concurrently with the lipid to stimulate release of lipoprotein lipase but thought it unnecessary because infusion of TG without heparin in the experiments previously mentioned successfully increased plasma NEFA concentration.

Table 6. Effects of treatment on rumen VFA and $\mathrm{pH}$ for cows at the end of the infusion period (infusion day, $2400 \mathrm{~h}$ )

\begin{tabular}{|c|c|c|c|c|c|c|c|c|}
\hline \multirow[b]{2}{*}{ Item } & \multicolumn{2}{|c|}{ Saline } & \multicolumn{2}{|c|}{ Lipid } & \multirow[b]{2}{*}{$\mathrm{SE}$} & \multicolumn{3}{|c|}{$P$-value ${ }^{1}$} \\
\hline & Control & Propionate & Control & Propionate & & Propionate & Lipid & Interaction \\
\hline \multicolumn{9}{|l|}{ Rumen VFA, mM } \\
\hline Total & 145 & 134 & 159 & 147 & 7.74 & 0.12 & 0.06 & 0.97 \\
\hline Acetic acid & 92.6 & 75.7 & 100.8 & 85.6 & 4.28 & 0.001 & 0.04 & 0.83 \\
\hline Butyric acid & 18.3 & 16.1 & 22.6 & 18.3 & 1.87 & 0.02 & 0.02 & 0.38 \\
\hline Isobutyric acid & 1.23 & 1.16 & 1.44 & 1.22 & 0.098 & 0.14 & 0.16 & 0.43 \\
\hline Isovaleric acid & 1.95 & 1.87 & 2.37 & 2.11 & 0.227 & 0.32 & 0.03 & 0.35 \\
\hline Propionic acid & 28.3 & 36.3 & 28.7 & 37.4 & 2.14 & 0.0001 & 0.62 & 0.83 \\
\hline \multicolumn{9}{|l|}{ Rumen VFA, \% } \\
\hline Acetic acid & 64.1 & 56.6 & 63.6 & 58.4 & 1.06 & $<0.0001$ & 0.39 & 0.11 \\
\hline Butyric acid & 12.6 & 11.9 & 14.2 & 12.2 & 0.79 & 0.002 & 0.02 & 0.10 \\
\hline Isobutyric acid & 0.81 & 0.89 & 0.90 & 0.82 & 0.063 & 0.91 & 0.87 & 0.14 \\
\hline Isovaleric acid & 1.26 & 1.37 & 1.47 & 1.41 & 0.118 & 0.74 & 0.15 & 0.30 \\
\hline Propionic acid & 19.6 & 27.5 & 18.1 & 25.4 & 0.95 & $<0.0001$ & 0.02 & 0.69 \\
\hline Rumen pH & 5.78 & 6.01 & 5.90 & 6.00 & 0.16 & 0.30 & 0.75 & 0.68 \\
\hline
\end{tabular}

${ }^{1}$ Interaction $=$ interaction between propionic acid and lipid infusion. 
The lack of effect of LI on yield of milk fat was surprising. However, Chelikani et al. (2003) reported that lipid infusion did not increase milk fat yield in late lactation, consistent with our results. Bareille and Faverdin (1996) reported that lipid infusion tended to increase milk fat yield while reducing de novo FA synthesis. The shift in FA profile observed by Bareille and Faverdin (1996) may explain our lack of response in milk fat yield. However, we did not measure milk FA profile, so this cannot be verified.

The lack of treatment effects of PI on changes in plasma and liver metabolite and plasma hormone concentrations is inconsistent with results of previous experiments using similar infusion rates. Intraruminal propionate infusions have increased plasma glucose (Sheperd and Combs, 1998; Oba and Allen, 2003a,c) and insulin (Oba and Allen, 2003a,c) concentrations, and decreased plasma BHBA (Sheperd and Combs, 1998; Oba and Allen, 2003a) and NEFA (Oba and Allen, 2003a) concentrations. However, Sheperd and Combs (1998) did not detect an effect of propionate infusion on plasma insulin or NEFA concentrations, consistent with the results of the current experiment. Cows in these experiments were all in mid to late lactation, and differences in plasma hormone and metabolite responses could be a result of differences in DMI, milk production, or lipolytic state between the experiments.

There are limited data reporting feeding behavior for cows fed fat or infused with lipid. Heinrichs et al. (1982) reported that feeding a higher fat concentrate mix resulted in decreased size and length of the conditioned meal (first meal following feeding). They speculated that this might have been because of reduced palatability or because satiety was reached sooner with the high fat feed. However, supplemental dietary fat has been shown to increase concentrations of gut peptides, which may lead to decreased DMI (Choi et al., 2000; Relling and Reynolds, 2007; Bradford et al., 2008). In the current experiment, LI numerically reduced the size of the first meal by $1.23 \mathrm{~kg}$ (5.39 vs. $6.62 \mathrm{~kg}$, not significant) and tended to reduce meal size overall, consistent with the reduction in the size of the conditioned meal reported by Heinrichs et al. (1982). The mechanism for the reduction in meal size by LI in the current experiment is unclear, as intravenous LI would not likely stimulate gut peptides or affect the palatability of the diet, and LI did not decrease total DMI because intermeal interval was decreased. Intravenous lipid infusion reduced DMI 14\% (Chelikani et al., 2003) and 5\% (Bareille and Faverdin, 1996) in previous experiments in which feeding behavior was not measured.

We have previously reported that intraruminal propionate infusion is more hypophagic for cows in a lipolytic state (Oba and Allen, 2003a; Stocks and Al- len, 2012, 2013). This is likely a result of propionate stimulating oxidation of hepatic acetyl CoA, resulting in a reduction of the concentration of hepatic acetyl CoA as previously observed (Stocks and Allen, 2013). In the current experiment, LI did not affect the hepatic acetyl CoA concentration at the termination of the infusion, and PI only tended $(P=0.09)$ to decrease hepatic acetyl CoA concentration compared with $\mathrm{CO}$ over the course of the infusion. This is inconsistent with our previous results in early lactation (Stocks and Allen, 2013) and consistent with the lack of an interaction between LI and PI for DMI and feeding behavior.

\section{CONCLUSIONS}

Experimentally increasing plasma NEFA concentration through intravenous lipid infusion to simulate the metabolic state of an early lactation cow was expected to allow for the investigation of cause and effect between lipolytic state and propionic acid infusion on DMI. However, this model failed to increase plasma NEFA concentration as previously reported by others, and therefore also failed to increase hepatic acetyl CoA concentration. Additional research investigating the interaction between propionic acid and lipid infusion, as well as between diet fermentability and lipolytic state, are necessary for determining feeding strategies for cows in the immediate postpartum period.

\section{ACKNOWLEDGMENTS}

We gratefully acknowledge D. G. Main and R. A. Longuski from Michigan State University (East Lansing) for technical assistance. This project was supported by National Research Initiative Competitive Grant no. 2008-35206-18854 from the US Department of Agriculture's National Institute of Food and Agriculture (to MSA) and by USDA National Needs Graduate Fellowship program grant number 2007-38420-17753 (to SES).

\section{REFERENCES}

AOAC. 1990. Official Methods of Analysis. 15th ed. Association of Official Analytical Chemists, Gaithersburg, MD.

AOAC International. 1997. Official Methods of Analysis. 16th ed. AOAC International, Gaithersburg, MD.

Bareille, N., and P. Faverdin. 1996. Lipid metabolism and intake behavior of dairy cows: Effects of intravenous lipid and $\beta$-adrenergic supplementation. J. Dairy Sci. 79:1209-1220.

Bell, A. W. 1995. Regulation of organic nutrient metabolism during transition from late pregnancy to early lactation. J. Anim. Sci. $73: 2804-2819$.

Bell, A. W., and D. E. Bauman. 1997. Adaptations of glucose metabolism during pregnancy and lactation. J. Mammary Gland Biol. Neoplasia 2:265-278.

Bradford, B. J., and M. S. Allen. 2005. Phlorizin administration increases hepatic gluconeogenic enzyme mRNA abundance but not feed intake in late-lactation dairy cows. J. Nutr. 135:2206-2211. 
Bradford, B. J., and M. S. Allen. 2007. Phlorizin administration does not attenuate hypophagia induced by intraruminal propionate infusion in lactating dairy cattle. J. Nutr. 137:326-330.

Bradford, B. J., A. D. Gour, A. S. Nash, and M. S. Allen. 2006. Propionic acid challenge test have limited value for investigating bovine metabolism. J. Nutr. 136:1915-1920.

Bradford, B. J., K. J. Harvatine, and M. S. Allen. 2008. Dietary unsaturated fatty acids increase plasma glucagon-like peptide- 1 and cholecystokinin and may decrease premeal ghrelin in lactating dairy cows. J. Dairy Sci. 91:1443-1450.

Chelikani, P. K., D. H. Keisler, and J. J. Kennelly. 2003. Response of plasma leptin concentration to jugular infusion of glucose or lipid is dependent on the stage of lactation of Holstein cows. J. Nutr. 133:4163-4171.

Choi, B. R., D. L. Palmquist, and M. S. Allen. 2000. Cholecystokinin mediates depression of feed intake in dairy cattle fed high fat diets. Domest. Anim. Endocrinol. 19:159-175.

Cochran, R. C.. D. C. Adams, J. D. Wallace, and M. L. Galyean. 1986. Predicting the digestibility of different diets with internal markers: Evaluation of four potential markers. J. Anim. Sci. 63:1476-1483.

Dado, R. G., and M. S. Allen. 1993. Continuous computer acquisition of feed and water intake, chewing reticular motility, and ruminal $\mathrm{pH}$ of cattle. J. Dairy Sci. 76:1589-1600.

Davis, C. L. 1967. Acetate production in the rumen of cows fed either control or low-fiber, high-grain diets. J. Dairy Sci. 50:1621-1625.

Doepel, L., H. Lapierre, and J. J. Kennelly. 2002. Peripartum performance and metabolism of dairy cows in response to prepartum energy and protein intake. J. Dairy Sci. 85:2315-2334.

Firkins, J. L., M. L. Eastridge, N. R. St-Pierre, and S. M. Noftsger. 2001. Effects of grain variability and processing on starch utilization by lactating dairy cattle. J. Anim. Sci. 79(E-Suppl.):E218E238.

Goering, H. K., and P. J. Van Soest. 1970. Forage Fiber Analysis (Apparatus, Reagents, Procedures, and Some Applications). Agricultural Handbook no. 379. Agricultural Research Service-US Department of Agriculture, Washington, DC.

Hach, C. C., B. K. Bowden, A. B. Lopelove, and S. V. Brayton. 1987. More powerful peroxide Kjeldahl digestion method. J. AOAC 70:783-787.

Heinrichs, A. J., D. L. Palmquist, and H. R. Conrad. 1982. Feed intake patterns of cows fed high fat grain mixtures. J. Dairy Sci. 65:1325-1328.

Karkalas, J. 1985. An improved enzymatic method for the determination of native and modified starch. J. Sci. Food Agric. 36:10191027 .

Mashek, D. G., S. J. Bertics, and R. R. Grummer. 2005. Effects of intravenous triacylglycerol emulsion on hepatic metabolism and blood metabolites in fasted cows. J. Dairy Sci. 88:100-109.
Mertens, D. R. 2002. Gravimetric determination of amylase-treated neutral detergent fiber in feeds using refluxing in beakers or crucibles: Collaborative study. J. AOAC Int. 85:1217-1240.

NRC. 2001. Nutrient Requirements of Dairy Cattle. 7th rev. ed. Natl. Acad. Press, Washington, DC.

Oba, M., and M. S. Allen. 2003a. Dose-response effects of intraruminal infusion of propionic acid on feeding behavior of lactating cows in early or mid lactation. J. Dairy Sci. 86:2922-2931.

Oba, M., and M. S. Allen. 2003b. Effects of corn grain conservation method on feeding behavior and productivity of lactating dairy cows at two dietary starch concentrations. J. Dairy Sci. 86:174183.

Oba, M., and M. S. Allen. 2003c. Extent of hypophagia caused by propionate infusion is related to plasma glucose concentration in lactating dairy cows. J. Nutr. 133:1105-1112.

Pires, J. A. A.. A. H. Souza, and R. R. Grummer. 2007. Induction of hyperlipidemia by intravenous infusion of tallow emulsion causes insulin resistance in Holstein cows. J. Dairy Sci. 90:2735-2744.

Relling, A. E., and C. K. Reynolds. 2007. Feeding rumen-inert fats differing in their degree of saturation decreases intake and increases plasma concentrations of gut peptides in lactating dairy cows. J. Dairy Sci. 90:1506-1515.

Reynolds, C. K., P. C. Aikman, B. Lupoli, D. J. Humphries, and D. E. Beever. 2003. Splanchnic metabolism of dairy cows during the transition from late gestation through early lactation. J. Dairy Sci. 86:1201-1217.

Roberts, T., N. Chapinal, S. J. LeBlanc, D. F. Kelton, J. Dubuc, and T. F. Duffield. 2012. Metabolic parameters in transition cows as indicators for early lactation culling. J. Dairy Sci. 95:3057-3063.

Seifi, H. A., S. J. LeBlanc, K. E. Leslie, and T. F. Duffield. 2011 Metabolic predictors of post-partum disease and culling risk in dairy cattle. Vet. J. 188:216-220.

Sheperd, A. C., and D. K. Combs. 1998. Long-term effects of acetate and propionate on voluntary feed intake by midlactation cows. J. Dairy Sci. 81:2240-2250.

Stocks, S. E., and M. S. Allen. 2012. Hypophagic effects of propionic acid increase with elevated hepatic acetyl coenzyme A concentration for cows in the early postpartum period. J. Dairy Sci 95:3259-3268.

Stocks, S. E., and M. S. Allen. 2013. Hypophagic effects of propionic acid are not attenuated during a three-day infusion in the early postpartum period in Holstein cows. J. Dairy Sci. 96:4615-4623. http://dx.doi.org/10.3168/jds.2013-6653.

Wildman, E. E., G. M. Jones, P. E. Wagner, R. L. Boman, H. F. Troutt Jr., and T. N. Lesch. 1982. A dairy cow body condition scoring system and its relationship to selected production characteristics. J. Dairy Sci. 65:495-501. 